\title{
Vistula river, its characteristics and management
}

\section{Introduction}

The Vistula is the main river in Poland, which flows from the mountains in the south to the Baltic Sea in the north. The importance of the Vistula is justified by high discharge, river length, and large catchment area. The average annual discharge of the Vistula to the Bay of Gdansk is more than thousand cubic meters per second. River length amounts to $1047 \mathrm{~km}$ from its source to the discharge point. Sometimes its length is divided into two sections: The Small Vistula (106 km in length) from the source to the tributary - Przemsza River, and the remaining part $941 \mathrm{~km}$ long, which is considered as Navigable Vistula. The whole run of the Vistula is on the terrain of Poland (Figure1). The Vistula catchment amounts to nearly 200 thousand $\mathrm{km}^{2}$ and $87 \%$ of this catchment is within Polish territory. The remaining part of the catchment $(13 \%)$ is in the neighboring countries. During more than thousand years of Polish history the Vistula created always a very important economic axis of the country. It was a unique transportation route and provided water and food for people who settled on its banks. The Vistula played also important cultural role in paintings, music and songs. Very often it was used during wars as a defensive line. During XVI, XVII and XVIII century the Vistula was a very important waterway connecting its catchment with Gdansk which was a harbor for import of various goods from Europe and export of timber, wheat and other agricultural products. Despite rather primitive means of water transport during this time, nearly quarter million tons of various products were transported downstream and upstream. At the end of XVIII century Poland was partitioned by Prussia, Russia and Austria. These countries divided Poland and the whole Vistula run into three sections. There was no cooperation between these countries and the Vistula lost its importance as navigable waterway. There was, however, significant engineering activity in the northern part of the river, which was occupied by Prussia. In the XVIII and XIX century most European rivers developed rapidly providing water, energy, food and means of transport for their countries economy. Good examples are Rhine, Rhone, Seine, Danube, or Volga.

Poland is the country of small water resources due to low precipitation and relatively high evaporation. One of the main problems in water management in Poland is small volume of retention reservoirs and high economic and social losses caused by floods and droughts. ${ }^{1}$ At present we are very often faced with different points of view concerning future management of the Vistula. Some people - mainly ecologists, regard the Vistula as a natural river. They consider that the Vistula, as Natural River, should be kept in this state and transferred to next generations. Water resources specialists do not regard the Vistula as Natural River, but as degraded one. This degradation is rapidly developing and the river does not bring adequate economic advantages (water supply, hydro-energy, navigation, flood protection) as in other EU countries. Every new proposed water reservoir or hydraulic structure presents strong opposition from ecologists. Moreover nearly the whole run of the Vistula is covered by the program Natura 2000. This makes the development of any new hydraulic construction nearly impossible. Polish Parliament regarding the Vistula as a very important river for our nature and economy established the year 2017 as the Year of Vistula River. ${ }^{2}$ Two years ago Poland ratified the AGN (Large European Navigable Rivers) agreement which indicates that

\author{
Volume 2 Issue 4 - 2018
}

\author{
Wojciech Majewski \\ Institute of Meteorology and Water Management, National \\ Research Institute, Poland
}

Correspondence: Wojciech Majewski, Institute of Meteorology and Water Management, National Research Institute, Poland, Email wojciechmajewski@ibwpan.gda.pl

Received: July 02, 2018 | Published: August 14, 2018

about $1700 \mathrm{~km}$ of Polish international navigable routs should be developed to the IV class. The aim of this publication is to present basic characteristics of the Vistula and its catchment, hydrologic data, existing main hydraulic structures on the Vistula and on its tributaries and possible plans for the future development.

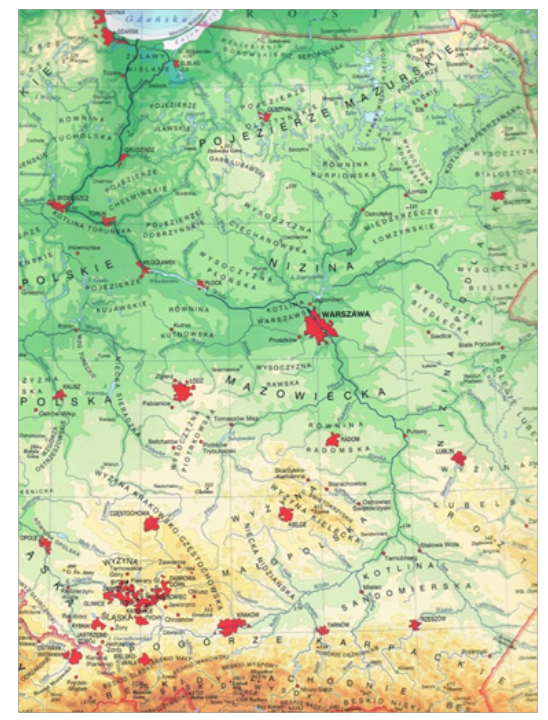

Figure I Map of the Vistula basin.

\section{The Vistula catchment}

The Vistula basin amounts to 194 thousand $\mathrm{km}^{2}$ and is located in the eastern part of Poland and occupies $54 \%$ of country area. The catchment, which is within Poland's territory has the area of 169 thousand $\mathrm{km}^{2}$. The remaining part of the catchment is in the territory of Belarus, Ukraine and Slovakia. The catchment of the Vistula, which is in Poland, is inhabited by about 20 million people. On this terrain there are many important cities, industrial centers, thermal power plants and agriculture areas, which require large amounts of water for their operation. The Vistula and its catchment vary along its course. This is caused by changing hydrologic conditions, configuration of the terrain, climatic conditions, hydraulic infrastructure and economy. Taking into account these aspects the Vistula and its basin are divided into three different parts (Figure 2). These are: Upper Vistula, Middle Vistula and the Lower Vistula. This division takes into account changing hydrologic conditions. The Upper Vistula and 
its catchment is from the river source to the tributary San. Along this course the Vistula receives several mountain tributaries which significantly change its discharge. The Middle Vistula is $256 \mathrm{~km}$ long and has the area of 89 thousand $\mathrm{km}^{2}$. The end of the Middle Vistula run is at the location of Narew tributary. The Lower Vistula run and its catchment begin at the Narew tributary and terminates in the Bay of Gdansk. ${ }^{2}$ Transported by the Vistula sediments are deposited at its mouth forming sedimentation cone. The length of the Lower Vistula is $391 \mathrm{~km}$ and its catchment amounts to 34 thousand $\mathrm{km}^{2}$.

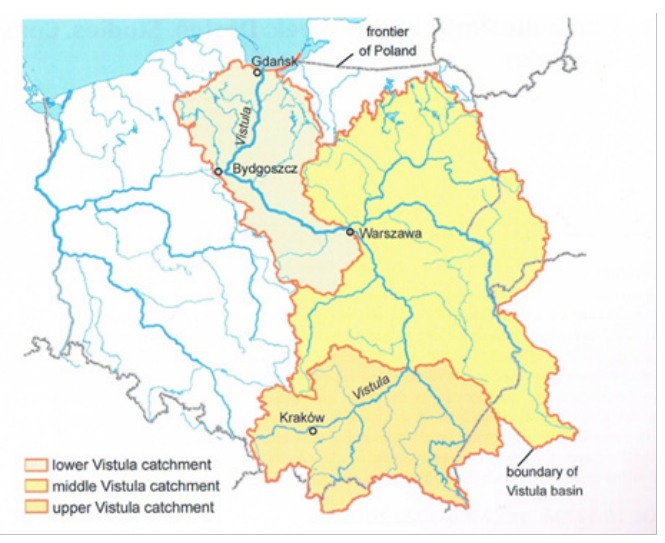

Figure 2 Division of the Vistula basin.'

\section{Hydrological data}

Change of the Vistula discharge along its course is presented in Table 1. These data are from the Institute of Meteorology and Water Management (IMGW) since 1950. ${ }^{1}$ The gauge Zawichost (km 287.6) terminates the Upper Vistula Section and the gauging station Modlin ( $\mathrm{km} \mathrm{551.5)}$ is at the end of the Middle Vistula. Gauge Tczew is about $30 \mathrm{~km}$ from the Vistula mouth, however, downstream from Tczew there are no tributaries and outflows. Therefore discharge at this gauge can be considered as final. In Table $1 \mathrm{SSQ}-$ is the average multiyear discharge, WWQ-maximum discharge which appeared during observation period, and NNQ-the lowest observed discharge. Discharge of the probability of $1 \%$ being exceeded is $8990 \mathrm{~m}^{3} / \mathrm{s}$. Such discharge was not observed at the outlet of the Vistula since the beginning of observation period. Flood dykes along the Lower Vistula section are designed for the flow of $1 \%$ probability. Baltic is a nontidal sea, however, there are variations in water level along the Polish coast. This variation is mainly due to wind upwelling and ranges up to $1.50 \mathrm{~m}$. Its influence is observed in the cross-section of gauge Tczew. The variation of water levels in this cross-section for maximum and minimum discharge range to about $5 \mathrm{~m}$. Interesting hydrologic data concern the annual runoff of the Vistula to the sea. It is estimated that the Vistula provides about $7 \%$ of fresh water to the Baltic Sea. The following annual Vistula runoffs to the sea were observed: maximum $50.8 \mathrm{~km}^{3}$ (wet year 1975), minimum $20.5 \mathrm{~km}^{3}$ (dry year 1952) and the average multiannual runoff is $34.0 \mathrm{~km}^{3}$.

The unit runoffs of the Vistula and parts of its catchment show that Poland has very low water resources in comparison to other European countries. These values for particular areas are as follows:
a. The Upper Vistula basin $9.161 /\left(\mathrm{s} \mathrm{km}^{2}\right)$
b. The river San basin: 7.71 1/( $\left.\mathrm{s} \mathrm{km}^{2}\right)$
c. The Middle Vistula river basin: $4.001 /\left(\mathrm{s} \mathrm{km}^{2}\right)$
d. The river Narew basin: $4.331 /\left(\mathrm{s} \mathrm{km}^{2}\right)$
e. The Lower Vistula basin: $5.181 /\left(\mathrm{s} \mathrm{km}^{2}\right)$
f. Total Vistula basin: $5.341 /\left(\mathrm{s} \mathrm{km}^{2}\right)$

Table I Characteristic discharge at the gauging stations along the Vistula course. Source: IMGW

\begin{tabular}{lllllll}
\hline $\begin{array}{l}\text { Gauging } \\
\text { station }\end{array}$ & $\begin{array}{l}\text { Kilo- } \\
\text { meter }\end{array}$ & $\begin{array}{l}\text { Catchment } \\
\text { area } \mathbf{~ k m}^{2}\end{array}$ & $\begin{array}{l}\text { Years } \\
\text { of } \\
\text { observation }\end{array}$ & $\begin{array}{l}\text { SSQ } \\
\mathbf{m}^{3} / \mathbf{s}\end{array}$ & $\begin{array}{l}\text { WWQ } \\
\mathbf{m}^{3} / \mathbf{s}\end{array}$ & $\begin{array}{l}\mathbf{N N Q} \\
\mathbf{m}^{3 / s}\end{array}$ \\
\hline $\begin{array}{l}\text { Nowy } \\
\text { Bieruń }\end{array}$ & 3.6 & 1780 & $1951-2011$ & 21.2 & 846 & 1.5 \\
Zawichost & 287.6 & 50665 & $1951-2011$ & 432 & 6160 & 110 \\
Modlin & 551.5 & 159724 & $1969-2011$ & 880 & 6860 & 232 \\
$\begin{array}{l}\text { Kepa } \\
\text { Polska }\end{array}$ & 606.5 & 168358 & $1969-2011$ & 940 & 6980 & 280 \\
Toruń & 734.7 & 180391 & $1951-2011$ & 971 & 6890 & 266 \\
Tczew & 908.6 & 193807 & $1951-2011$ & 1055 & 6490 & 264 \\
\hline
\end{tabular}

\section{Climate conditions}

Climate in any catchment decides on hydrologic conditions and especially on water resources. The main meteorological factors which decide on the climate are: precipitation, air temperature and humidity. These data for the Vistula catchment are cited on the basis of The Atlas of the Climate of Poland, ${ }^{3}$ compiled from 60 weather stations. The main climatic parameter is precipitation and its spatial and temporal distribution The highest precipitation, exceeding $1100 \mathrm{~mm}$ (mean multiannual precipitation) occurs in the mountains in the upper part of the catchment. The lowest precipitation $(550 \mathrm{~mm})$, has been recorded in central Poland. This is very important, because in this area agriculture plays dominant role. Slightly higher precipitation $(600 \mathrm{~mm})$ occurs at the mouth of the Vistula River. Uneven temporal distribution of precipitation was always observed in the Vistula catchment. High values were observed in summer months in the mountains, which was the cause of frequent floods. Now we observe much higher differentiation of precipitation both in time and space. This is mainly due to climate changes. The mean annual long-term precipitation in the Vistula basin is estimated at $610 \mathrm{~mm}$. Distribution of the mean annual precipitation in Poland is shown in Figure 4.

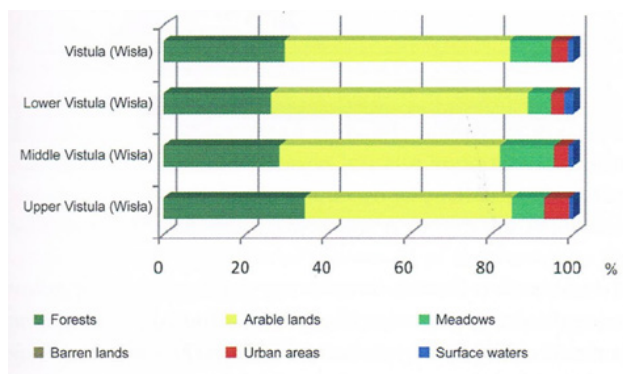

Figure 3 Land cover of the Vistula catchment.'

\section{The Vistula basin land cover}

Land cover in a similar way as climatic conditions influences water resources and their management in the catchment. ${ }^{1}$ Cornie Land Cover distinguishes six types of land cover: forests, arable land, meadows, barren land, urban areas and surface water. The land 
cover in particular parts of the Vistula basin is shown in Figure 3. The area of the arable land is the most common in all parts of the catchment. Forests occupy smaller part of the catchment. In all three basin areas of the Vistula River, the land cover areas are similar. The forestation, which is very important for water retention is the highest in the catchment area of the Upper Vistula. The highest portion of arable land is to be found in the catchment area of the Lower Vistula.

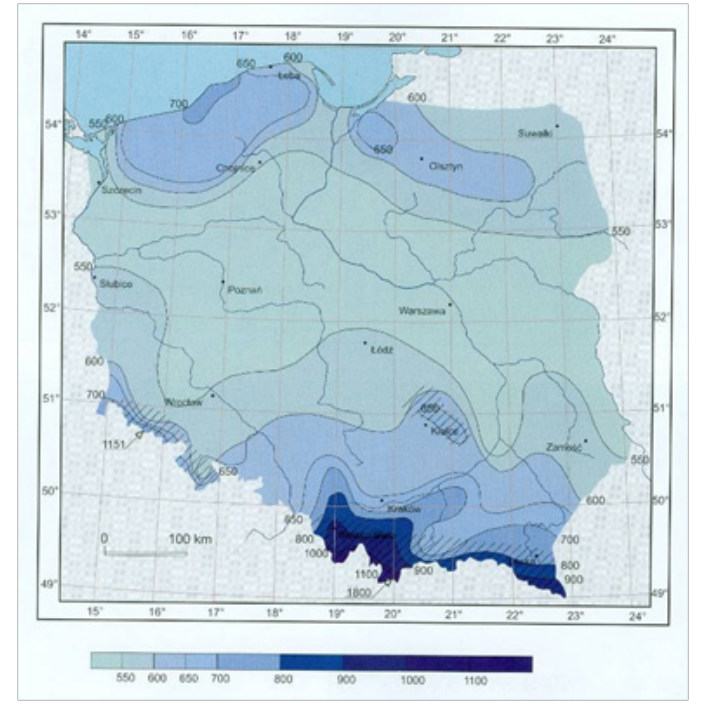

Figure 4 Distribution of mean annual precipitation in Poland. ${ }^{3}$

\section{Hydraulic facilities on the Vistula and its tributaries}

Water resources management in any form like water supply, hydroenergy, inland navigation, flood protection, cooling water systems or recreation require the assistance of various hydraulic structures. These are dams, weirs, navigation locks, flood dykes, training structures or recreation water facilities. Vistula River and its catchment played always a very important role in Poland's water resources management. Various types of hydraulic facilities were constructed in different times and with different aims on the Vistula River and on its tributaries. The comprehensive review of these structures can be found in the monograph published on the occasion of the Year of Vistula River. It would be difficult to present here majority of them and therefore only three most important will be described. These are: CzorsztynNiedzica (Dunajec river), Solina (river San) and Wloclawek (the Lower Vistula).

\section{The Czorsztyn-Niedzica dam}

The Czorsztyn-Niedzica Dam was commissioned in 1997 just before the advent of high flood wave on the Dunajec River (right tributary of the Vistula). The flood wave filled the empty reservoir $\left(232 \mathrm{hm}^{3}\right)$ and thus decreased flood danger downstream of the dam. Earthfill dam is located in $\mathrm{km} 173.0$ of the Dunajec River (Figure 5). The dam is $54 \mathrm{~m}$ high and is equipped with surface spillway and outlet works. Its basic aim is flood protection, production of electricity and recreation. The hydroelectric plant of the capacity of $92 \mathrm{MW}$ is equipped with reversible turbines. Due to located downstream equilibrium reservoir the power plant can operate in pumped storage system. Equilibrium reservoir secures also biological flow in Dunajec river of $9 \mathrm{~m}^{3} / \mathrm{s}$. Due to the reservoir (recreation) and power-plant (electricity production) considerable development of this poor region took place.

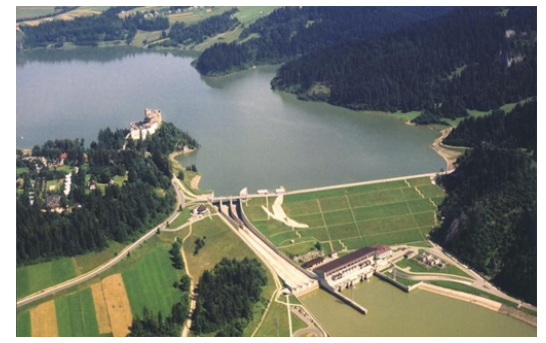

Figure 5 Czorsztyn-Niedzica dam on the Dunajec River (downstream view) ${ }^{4}$

\section{Solina dam}

Solina Dam was commissioned in 1968 as one of the projects of the planned San cascade. Solina is concrete gravity dam 60 high located at km 325.0 of San River. The main aim of the project was flood protection, electricity production and recreation. The dam forms a reservoir of the volume $472 \mathrm{hm}^{3}$. The dam has three bay spillway and two outlet works (Figure 6). The hydroelectric plant with installed power of $200 \mathrm{MW}$ is equipped with reversible turbines. Downstream equilibrium reservoir allows its operation in pumped storage system.

Hydraulic project Wloclawek : On the Lower Vistula situated at km 675,0 was commissioned in 1970 and forms run-off-river reservoir with initial volume of $400 \mathrm{hm}^{3}$ and was designed as the first project of the Lower Vistula Cascade. ${ }^{5}$ The aim of the cascade was the production of electric energy, formation of navigable waterway, water supply and flood protection. Project consists of earth dam, 10 bay weir with gates and spillways, hydraulic power plant of the capacity 160MW (6 units) and energy production $750 \mathrm{GWh}$ in an average hydrological year (Figure 7). Till today Wloclawek barrage operates as single project causing considerable local erosion downstream. ${ }^{4}$ The only solution for this problem is the construction of next barrage downstream. ${ }^{6}$

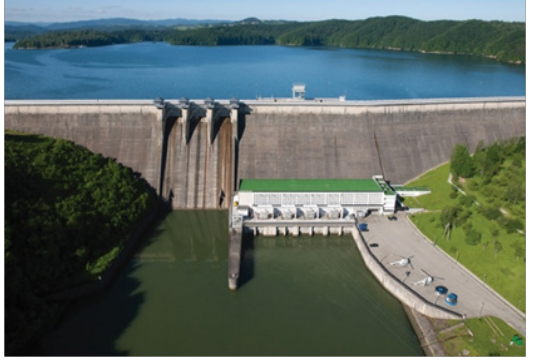

Figure 6 Solina dam on the San River (downstream view). ${ }^{4}$

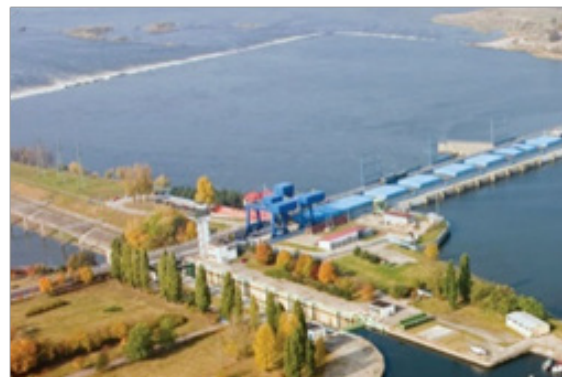

Figure 7 Wloclawek barrage on the LowerVistula. ${ }^{4}$ 


\section{Floods and droughts}

Floods and droughts appear on the Vistula and its catchment very often causing very high economic social and also very often ecological losses. Floods have rather regional character. In the upper Vistula catchment they appear in spring due to rapid melting of large amounts of ice and snow in the mountains. The second possibility is very intensive rains in summer, which cause increase of discharge and very often breaching of flood dykes. On the Lower Vistula the main floods are due to ice phenomena, which appear in the beginning of winter during formation of ice cover and also in spring during ice break-up and ice-run. ${ }^{6}$ These ice situations very often lead to ice jams resulting in high water stages and floods.

\section{Plans for future development of vistula}

In the past there were numerous plans and projects for the development of Vistula and its catchment. Unfortunately none of them was realized mainly due to economic reasons and protests from various ecological organizations. Recently Poland signed the AGN Convention, concerning international inland waterways, which obliges Poland to develop some of our rivers into international navigable waterways (class IV), which includes the whole section of the Lower Vistula.

\section{Acknowledgements}

None.

\section{Conflict of interest}

The author declares there is no conflict of interest.

\section{References}

1. Majewski W. General characteristics of the Vistula and its basin. Acta Energetica. 2013;15.

2. Majewski W. Monograph of the Lower Vistula. IMGW, Warsaw (in Polish). 2016.

3. Lorenc H. The Atlas of the Climate of Poland. IMGW (in Polish). 2005.

4. Majewski W. 2017-The Year of the Vistula River. IMGW, Warsaw (in Polish). 2018.

5. Cascade of the Lower Vistula River. Warsaw: PROEKO. 1993.

6. Majewski W. Flow in Open Channels under the influence of ice phenomena. IMGW, Warsaw (in Polish). 2009.

7. Majewski W. Next barrage on the Lower Vistula, a threat or a necessity. Water Resources Management (in Polish). 2012;10. 